\title{
JURNAL BIMBINGAN DAN KONSELING
}

UMP

http://journal.umpalangkaraya.ac.id/index.php/suluh Volume 6 Nomor 1, September 2020 (1-7)

\section{APAKAH SPIRITUAL EMOTIONAL FREEDOM TECHNIQUE DAPAT MENURUNKAN PERILAKU AGRESI? \\ Does The Freedom Technique Emotional Spiritual Can Reduce Aggressive Behavior?}

'Akhmad Liana Amrul Haq dan ${ }^{2}$ Minzani Aufa

IUniversitas Muhammadiyah Magelang, Magelang, Jawa Tengah, Indonesia

2Universitas Muhammadiyah Magelang, Magelang, Jawa Tengah, Indonesia

\section{ARTIKEL INFO}

Diterima

Dipublikasi

September 2020 *e-mail :

!akuamrulhaq@ummgl .ac.id,

${ }^{2}$ minzaniaufa@ummgl. ac.id

Orcid :

\section{ABSTRAK}

Tujuan dari penelitian ini adalah mengetahui efektifitas terapi Spiritual Emotional Freedom Technique (SEFT) untuk menurunkan perilaku agresi siswa. Subjek dalam penelitian ini adalah siswa di SMP Muhammadiyah Srumbung, subjek dalam penelitian ini berjumlah 30 siswa yang dibagi menjadi tiga kelompok yakni satu kelompok eksperimen (KE), satu kelompok kontrol satu (KKI) dan satu kelompok kontrol dua (KK2). Data dalam penelitian ini dikumpulkan menggunakan skala agresi, desain eksperimen yang digunakan dalam penelitian ini adalalah Solomon Three Group Design. Nilai post test antara kelompok eksperimen dengan kelompok kontrol satu yang dianalisis menggunakan teknik teknik Mann Whitney $U$ diperoleh Asymp. Sig sebesar $0,014(p<0,05)$. Nilai post test antara kelompok eksperimen dengan kelompok kontrol satu yang dianalisis menggunakan teknik teknik Mann Whitney $U$ diperoleh Asymp. Sig sebesar 0,031 $(p<0,05)$. Hasil analisis data di atas menunjukkan bahwa Spiritual Emotional Freedom Technique (SEFT) efektif menurunkan perilaku agresi, guru dan orang tua dapat menggunakan Spiritual Emotional Freedom Technique (SEFT) sebagai salah satu cara menurunkan perilaku agresi.

Kata kunci: SEFT, Perilaku Agresi, Solomon Three Group Design.

\section{ABSTRACT}

The purpose of this study was to determine the effectiveness of the therapy of Spiritual Emotional Freedom Technique (SEFT) to reduce students' aggression behavior. The subjects in this study were students at Muhammadiyah Srumbung Middle School with a total of 30 students divided into three treatment groups, namely the experimental group, the control group one and the control group two. The data collection of this study uses the scale of aggression, the experimental research design used in this study is Solomon Three Group Design. The post test scores between the experimental group and the control group one were analyzed using the Mann Whitney $U$ technique obtained by Asymp. Sig of 0.014 ( $p$ $<0.05)$. The post test scores between the experimental group and the control group one were analyzed using the Mann Whitney $U$ technique obtained by Asymp. Sig of 0.031 ( $p$ $<0.05$ ). The results of the data analysis above show that Spiritual Emotional Freedom Technique (SEFT) is effective in reducing aggression, teachers and parents can use Spiritual Emotional Freedom Technique (SEFT) as a way to reduce aggression behavior.

Keywords: SEFT, Agression Behavior, Solomon Three Group Design. 
Jurnal Bimbingan dan Konseling

\section{PENDAHULUAN}

Renstra Kementerian Pendidikan dan Kebudayaan tahun 2015-2019 (Kebudayaan, 2015) membahas permasalahan dan tantangan pembangunan pendidikan dan kebudayaan bagi jenjang Menengah Pertama tentang gejala memudarnya karakter siswa, meningkatnya kasus-kasus penyalahgunaan NAPZA, dan tawuran antar kelompok maupun sekolah bisa diasumsikan sebagai gejala hilangnya pemahaman dan penanaman tentang nilai-nilai luhur budaya bangsa. Munculnya berbagai macam perilaku agresi pada akhir-akhir ini merupakan sebuah hal yang menarik untuk dikaji lebih jauh, semua bentuk kasus-kasus yang terjadi sangatlah merugikan berbagai pihak dan perlu adanya pencarian solusi dari masalah ini atau setidaknya mengurangi. Hal ini menjadi penting mengingat di pundak para remaja inilah perjuangan meneruskan bangsa ini diestafetakan. Apabila remaja sebagai penerus bangsa sudah membudidayakan pertengkaran dan perkelahian mau dibawa kemanakah nasib rakyat bangsa ini di masa depan. Berdasarkan hasil wawancara kepada Guru Agama di SMP Muhammadiyah Srumbung di dapatkan hasil bahwa setiap hari ada keluhan terhadap siswa-siswi yang merusak fasilitas sekolah maupun berkata-kata kurang sopan bila sedang marah. (Koeswara, 1998) menyebutkan perbuatan yang dapat menimbulkan kerusakan atau kesakitan pada sasaran atau korban termasuk dalam bentuk perbuatan agresi.

Pada umumnya manusia memiliki dua bagian emosi yaitu emosi positif dan emosi negatif. Perilaku agresi termasuk ke dalam emosi negatif yang muncul dari kesadaran diri seseorang terhadap suatu tindakan yang tidak seharusnya, munculnya perilaku negatif juga dapat disebabkan karenakan adanya ketidaksesuaian antara tindakan dengan nilai, norma dan moral yang berlaku dalam masyarakat dan pada akhirnya membuat individu untuk memperbaiki tindakan yang salah tersebut. (M. Nisfiannor, 2005). (Sulifan \& Muhid, 20I4) menjelaskan SEFT adalah salah satu varian dari satu cabang ilmu baru yaitu energy psychology. SEFT merupakan salah satu metode terapi psikologi yang menggabungkan antara spiritual power dan energy psychology dengan fokus untuk mengendalikan emosi dan pikiran. (Zainuddin, 2009) juga mengatakan terapi SEFT mampu untuk mengatasi permasalahan emosi seseorang. Penelitian yang dilakukan oleh (Warsito, Si, Darminto, Si, \& Lukitaningsih, 20I3) menyebutkan SEFT dapat menurunkan kecemasan pada siswa yang akan mengikuti ujian nasional.

(Safitri \& Sadif, 20I3) juga mengangkat terapi yaitu SEFT untuk menurunkan depresi pasien yang melakukan cuci darah, hasilnya menyebutkan terapi SEFT efektif untuk menurunkan tingkat depresi pasien yang sedang melakukan cuci darah. Terdapat dua perbedaan pada penelitian ini, dibandingkan dengan penelitian-penelitian sebelumnya. Perbedaan pertama terletak pada penelitian ini ingin mengukur efektifitas terapi SEFT untuk menurunkan perilaku agresi pada siswa. perbedaan kedua terletak pada metode pengambilan data, dalam penelitian ini metode pengambilan data yang digunakan berbentuk eksperimen dengan menggunakan Solomon Three group Desaign, desain penelitian ini menggunakan tiga kelompok perlakuan yaitu satu kelompok eksperimen dan dua kelompok kontrol. Hipotesis yang diajukan dalam penelitian ini adalah Pelatihan SEFTefektif untuk menurunkan perilaku agresi siswa. Siswa yang mengikuti pelatihan SEFT (kelompok eksperimen) akan memiliki skor perilaku agresi yang rendah dibandingkan siswa yang tidak mengikuti pelatihan SEFT (kelompok kontrol).

\section{METODOLOGI PENELITIAN}

Subjek dalam penelitian ini adalah siswa 
SMP Muhammadiyah Srumbung yang berjumlah 30 siswa, keseluruhan subjek diacak dan dimasukkan kedalam tiga (3) kelompok perlakuan yang berbeda-beda. Penelitian ini berbentuk true eksperimen menggunakan desain milik Solomon bernama Solomon Three group Desaign, subjek dalam penelitian ini dibagi menjadi tiga kelompok perlakuan yaitu 10 subjek menjadi kelompok eksperimen, 10 subjek menjadi kelompok kontrol satu dan 10 subjek menjadi kelompok kontrol dua. Gambaran desain eksperimen Solomon Three group Desaign yang dilakukan dapat dilihat pada tabel di bawah ini:

Tabel I. Rancangan Eksperimen

\begin{tabular}{llll}
\hline Kelompok & $\begin{array}{l}\text { Pre } \\
\text { test }\end{array}$ & Perlakuan & $\begin{array}{l}\text { Post } \\
\text { test }\end{array}$ \\
Eksperimen & E Pre & SEFT & E Post \\
Kontrol Satu & KI & & KI \\
& Pre & & Post \\
Kontrol Dua & - & SEFT & K2 \\
& & & Post
\end{tabular}

Keterangan:

E Pre : Pengukuran perilaku agresi (pre test) pada kelompok eksperimen

E Post : Pengukuran perilaku agresi (post test) pada kelompok eksperimen

KI Pre : Pengukuran perilaku agresi (pre test) pada kelompok kontrol satu

KI Post: Pengukuran perilaku agresi (post test) pada kelompok kontrol satu

K2 Post: Pengukuran perilaku agresi (post test) pada kelompok kontrol dua

Kelebihan desain milik Solomon ini yaitu KK2 berfungsi sebagai pengendali, karena KK2 ini tidak diberi pretest akan tetapi diberi intervensi dan post test. Penilaian hasil dari perlakuan yang telah diberikan yaitu dengan cara membandingkan skor post test dari ketiga kelompok diatas. Apabila hasil dari KE memperoleh angka yang secara signifikan lebih tinggi dibandingkan dengan KKI masih belum bisa diyakini bahwa perbedaan tersebut disebabkan karena perlakuan yang dilakukan. Adanya KK2 dapat meminimalisir kemungkinan KE belajar pada saat mengerjakan pre test, Apabila angka yang diperoleh KK2 secara signifikan lebih tinggi dibandingkan dengan hasil KKI, maka perlakuan yang telah diberikan benar-benar berpengaruh pada perubahan skor post test karena KK2 tidak diberikan pre test.

Pengukuran perilaku agresi pada penelitian ini memakai skala agresi yang disusun berdasarkan bentuk-bentuk agresi menurut (Morgan, C. T., \& King, R. A. Weisz. JR, \& Schopler, 1986), mereka berpendapat bahwa terdapat delapan bentuk-bentuk agresi yang meliputi; fisik, pasif, langsung; fisik, aktif, tidak langsung; fisik, pasif, langsung; fisik, pasif, tidak langsung; verbal, aktif, langsung; verbal, aktif, tidak langsung; verbal, pasif, langsung dan verbal, pasif, tidak langsung. Jika nilai dari skala agresi tinggi maka subjek memiliki tingkat perilaku agresi tinggi. Namun sebaliknya, jika nilai skala agresi rendah maka subjek memiliki tingkat perilaku agresi rendah. Pengujian hipotesis dalam penelitian menggunakan teknik Many Wit You (Arikunto, 20I0).

\section{HASIL DAN PEMBAHASAN}

Skala perilaku agresi yang disusun berdasarkan pendapat (Morgan, C. T., \& King, R. A. Weisz. JR, \& Schopler, 1986) memperoleh nilai reliabilitas sebesar 0,893 , hal ini berarti skala tersebut dapat digunakan sebagai alat ukur perilaku agresi. Uji normalitas alat ukur perilaku agresi menggunakan Kolmogorov-Smirnov Test (KSZ) sebesar 0,162 dan $p$ 0,044 p>0,05), artinya hasil penelitian ini tidak dapat digeneralisasikan terhadap populasi dan tidak dapat dianalisis menggunakan statistik 
Jurnal Bimbingan dan Konseling

parametrik. Hasil uji homogenitas menunjukkan Levene Statistic I,918 dengan sig $0,166$ ( $p>0,05)$, artinya karakteristik subyek penelitian dalam penelitian ini bersifat homogen.

\section{Tabel.2:}

Nilai pres test dan post test Kelompok Eksperimen dan Kelompok Kontrol I

post - pre KE post - pre KKI
0,03I $(p<0,05)$, terdapat perbedaan perilaku agresi antara kelompok satu yang tidak diberikan Spiritual Emotional Freedom Technique (SEFT) namun diberikan pre test dengan kelompok kontrol dua yang tidak diberikan pre test namun diberikan Spiritual Emotional Freedom Technique (SEFT). Artinya penurunan perilaku agresi pada kelompok eksperimen benar-benar disebabkan karena perlakuan yang diberikan.

Tabel.4:

\begin{tabular}{lcl}
\hline$-2,346^{\mathrm{b}}$ & $-\mathrm{I}, 634^{\mathrm{b}}$ \\
\hline 019 &, 102 \\
\hline & Pada kelompok eksperimen terjadi
\end{tabular}
perubahan skor pre test dan post test yang dianalisis menggunakan Wilcoxon Signed Rank Test diperoleh hasil Z -2,346 dengan Asymp. Sig sebesar 0,019 $(p<0,05)$, berbeda dengan hasil yang diperoleh kelompok kontrol satu yang dianalisis menggunakan Wilcoxon Signed Rank Test diperoleh hasil -I,634 dengan Asymp. Sig sebesar 0,102 $(p<0,05)$. Nilai post test antara kelompok eksperimen dengan kelompok kontrol satu yang dianalisis menggunakan teknik Mann Whitney $U$ diperoleh Asymp. Sig sebesar 0,0l4 ( $<<0,05)$, terdapat perbedaan perilaku agresi antara kelompok eksperimen yang diberi perlakuan berupa Spiritual Emotional Freedom Technique (SEFT) dengan kelompok kontrol satu yang tidak diberi perlakuan. Artinya Spiritual Emotional Freedom Technique (SEFT) efektif untuk menurunkan perilaku agresi.

Tabel.3:

Nilai post test antara $\mathrm{KE}$ dengan $\mathrm{KK}$ I

\begin{tabular}{ll}
\hline$Z$ & $-2,463$ \\
\hline Asymp. Sig & 0,014 \\
\hline
\end{tabular}

Nilai post test antara kelompok eksperimen dengan kelompok kontrol satu yang dianalisis menggunakan teknik teknik Mann Whitney $U$ diperoleh Asymp. Sig sebesar

Z $-2,163$

Tujuan penelitian ini adalah mengetahui efektifitas terapi Spiritual Emotional Freedom Technique (SEFT) untuk menurunkan perilaku agresi siswa, berdasarkan hasil analisis data di atas dapat disimpulkan bahwa Spiritual Emotional Freedom Technique (SEFT) efektif untuk menurunkan perilaku agresi siswa di SMP Muhammadiyah Srumbung. Zainuddin (2009) mengungkapkan bahwa terapi Spiritual Emotional Freedom Technique (SEFT) adalah salah satu varian dari satu cabang ilmu baru yaitu energy psychology. Spiritual Emotional Freedom Technique (SEFT) merupakan penggabungan antara spiritual power dan energy psychology. Efek dari penggabungan antara spiritual dan energy psychology ini dinamakan amplifiying effect (efek pelipatgandaan), sebelum terapi dilakukan terapis mengidentifikasi terlebih dahulu perilakuperilaku agresi yang muncul dalam kelompok tersebut sehingga masing-masing subjek memiliki satu target perilaku agresi yang akan diturunkan menggunakan terapi SEFT. Perlakuan dalam penelitian ini dilakukan secara klasikal, dalam pelaksanaannya terapi SEFT memiliki 6 tahap yang harus di lakukan, pertama pemberian estimasi nilai sebelum

Asymp. Sig $\quad 0,031$


Jurnal Bimbingan dan Konseling

dilakukan terapi, proses ini dilakukan dengan cara terapis menanyakan kepada masingmasing subjek untuk menentukan nilai dari rentang angka $\mathrm{I}-\mathrm{IO}$, nilai ini dimaksudkan untuk melihat seberasa tinggi perilaku agresi yang dimiliki oleh subjek sebelum terapi diberikan, (Yuniarsih, Ropi, \& Maryati, 20I5) menjelaskan bahwa setiap orang pasti memiliki kecemasan terhadap perilakuperilaku yang dapat merugikan orang lain, nilai pre-terapi ini menjadi salah satu tolak ukur akan keberhasilan terapi Spiritual Emotional Freedom Technique (SEFT). Tahapan kedua adalah The Set-Up, tujuannya adalah untuk memastikan agar aliran energi tubuh terarahkan dengan tepat. Langkah ini dilakukan untuk menetralisir psychological reversal atau perlawanan psikologis (biasanya berupa pikiran negatif spontan atau keyakinan bawah sadar negatif). Cara menetralisir psychological reversal tersebut adalah dengan melakukan the set-up words. Dalam bahasa religius, the set-up words adalah doa kepasrahan kepada Allah SWT. Sebagai Contoh "Ya Allah, walaupun saya masih sering berkata kasar, berbohng dan memukul teman, saya pasrahkan kepadaMu. Ya Allah, saya ikhlas saya pasrah". Pendapat yang dikemukakan oleh (Mulyo, 2007) mengungkapkan bahwa pada tahap ini seseorang akan merasa ikhlas dan memasrahkan semuanya kehendaknya kepada Allah SWT, bentuk kepasrahan ini sebagai wujud bahwa manusia hanya menjalankan apa yang sudah digariskan.

Tahap ketiga adalah dengan melakukan tune-in, dalam penelitian ini subjek penelitian diminta untuk memikirkan sesuatu atau peristiwa spesifik tertentu yang dapat membangkitkan emosi negatif yang akan dihilangkan, tujuannya adalah untuk secara spesifik menetralisir emosi negatif atau sakit fisik yang dirasakan. Untuk membantu terjadinya tune-in subjek penelitian diminta untuk menekan anggota tubuh yang dirasa sakit ketika memikirkan sesuatu yang membangkitkan respon emosi negatif tersebut. Tahap keempat adalah tapping yaitu mengetuk ringan dengan dua ujung jari pada titik-titik tertentu di tubuh sebanyak tujuh kali ketukan sambil terus melakukan tune-in, beberapa bagian tubuh yang diketuk sebanyak 5-7 kali ketukan adalah pada bagian top of head (bagian atas kepala), end of eyebrow (titik permulaan alis mata), side of eye (samping alis mata), under eye ( $2 \mathrm{~cm}$ di bawah mata), under nose (di bawah hidung), chin (antara dagu dan bagian bawah bibir), collarbone (pada ujung tempat bertemu tulang dada dan tulang rusuk pertama), under arm (untuk laki-laki terletak di bawah ketiak sejajar dengan putting susu dan wanita terletak di perbatasan antara tulang dada dan bagian bawah payudara), gamut (di bagian antara perpanjangan tulang jari manis dan tulang jari kelingking), karate point (di samping telapak tangan). Tahap kelima adalah Nine gamut procedure yaitu sembilan gerakan untuk merangsang otak. Setiap gerakan dimaksudkan untuk merangsang bagian otak tertentu. Sembilan gerakan tersebut adalah: I) Menutup mata, 2) Membuka mata, 3) Mata digerakkan dengan kuat ke kanan bawah, 4) Mata digerakkan dengan kuat ke kiri bawah, 5) Memutar bola mata searah jarum jam, 6) Memutar bola mata berlawanan arah jarum jam, 7) Bergumam dengan berirama selama dua detik, 8) Menghitung satu, dua, tiga, empat, dan lima, 9) Bergumam lagi seperti langkah ke-7. Menurut (Etika, Haryuni, \& Sulistya, 2018) menjelaskan bahwa Nine gamut procedure dapat menyelaraskan kinerja antara otak kanan dan otak kiri. Tahap keenam adalah pemberian estimasi nilai setelah dilakukan terapi, pada tahap ini terapis menanyakan kepada subjek untuk menentukan nilai seberapa tinggi perilaku agresi yang dimiliki oleh subjek setelah terapi diberikan.

Perlakuan berupa terapi Spiritual Emotional Freedom Technique (SEFT) diberikan 
Jurnal Bimbingan dan Konseling

selama dua pertemuan, setiap pertemuan dilakukan tiga kali putaran Spiritual Emotional Freedom Technique (SEFT), berdasarkan hasil observasi selama perlakuan diberikan ditemukan bahwa subjek yang berada pada kelompok eskperimen maupun kelompok kontrol dua mempunyai antusiasme yang bagus. (Zainuddin, 2009) mengatakan bahwa Spiritual Emotional Freedom Technique (SEFT) merupakan terapi yang mudah digunakan dan bisa diaplikasikan dalam kehidupan sehari-hari. Pada penelitian-penelitian sebelumnya terapi Spiritual Emotional Freedom Technique (SEFT) banyak digunakan di dunia kesehatan seperti penelitian yang dilakukan oleh (Masyitah, 2013) yang menggunakan terapi Spiritual Emotional Freedom Technique (SEFT) untuk menurunkan tekanan darah pada pasien hipertensi, hasil penelitian ini mengungkapkan bahwa Spiritual Emotional Freedom Technique (SEFT) efektif untuk menurunkan tekanan darah pada pasien yang menderita hipertensi. Terapi Spiritual Emotional Freedom Technique (SEFT) ini juga banyak digunakan untuk menghilangkan perilaku-perilaku sosial yang mengganggu, penelitian yang dilakukan oleh (Komariah, 2012) menggunakan Spiritual Emotional Freedom Technique (SEFT) sebagai salah satu terapi untuk menurunkan intensitas merokok, hasil penelitian ini menjelaskan bahwa Spiritual Emotional Freedom Technique (SEFT) bisa digunakan untuk menurunkan perilaku merokok pada mahasiswa. Keunikan dalam penelitian ini adalah menggunakan Spiritual Emotional Freedom Technique (SEFT) sebagai salah satu terapi dalam dunia pendidikan, (Yoo Hong Sik \& Hwang Jae, 2016) dalam tulisannya menjelaskan bahwa secara tidak sadar perkembangan teknologi terutama internet dapat menjadi pemicu perilaku agresi baik secara sadar maupun tidak sadar, lebih lanjut (Siregar \& Muljono, 2018) mengungkapkan bahwa game yang ditawarkan oleh internet saat ini memiliki unsur-unsur kekerasan yang sangat banyak.
Hasil wawancara kepada beberapa subjek penelitian menyebutkan beberapa perilaku agresi yang hilang selama terapi berlangsung adalah bentuk agresi verbal seperti berkata kasar dan mengumpat, banyak subjek mengungkapkan bahwa bentuk agresi verbal yang dilakukan tidak hanya di sekolah melainkan juga saat di rumah, (Pronina, 2018) menjelaskan bahwa berbagai bentuk agresi verbal dapat muncul juga karena faktor belajar sosial, lingkungan tempat tinggal juga berpengaruh memunculkan bentuk-bentuk perilaku agresi baik fisik maupun verbal.

\section{KESIMPULAN}

SEFT dapat menjadi salah satu terapi untuk menurunkan perilaku agresi siswa, hasil penelitian ini menjelaskan bahwa penurunan skor perilaku agresi pada KE disebabkan karena perlakuan berupa SEFT bukan karena faktor belajar pre-test. SEFT bisa digunakan sebagai salah satu cara yang praktis dan sederhana guna menurunkan perilaku agresi dalam kehidupan sehari-hari. Peneliti selanjutnya yang tertarik untuk mengkaji SEFT dapat melihat efektifitas terapi di luar bidang kesehatan dan pendidikan, bagi peneliti yang ingin menggunakan SEFT sebagai teknik terapi, dapat dilakukan secara individual bukan klasikal.

\section{Ucapan Terima Kasih}

$\begin{array}{llr}\text { Terima kasih kami } & \text { sampaikan } \\ \text { kepada } & \text { Rektor } & \text { Universitas } \\ \text { Muhammadiyah } & \text { Magelang } & \text { yang }\end{array}$
dijembatani LP3M memunculkan sebuah Program PRVI (Penelitian Revitalisasi Visi Institusi) sehingga tulisan ini dapat terselesaikan. Terima kasih juga kami sampaikan kepada SMP Muhammadiyah Srumbung yang bersedia menjadi tempat penelitian. 
Jurnal Bimbingan dan Konseling

DAFTAR PUSTAKA

Adawiyah, Robiatul. 2016. Profesionalitas Guru dan Pendidikan Karakter (Kajian Empiris di SDN Kabupaten Balangan). Lampung: Universitas negeri Lampung Mangkurat

Aulia, L. Rani. 2016. Implementasi Nilai Religius Dalam Pendiidkan Karakter Bagi Peserta Didik di Sekolah Dasar Juara Yogyakarta. Yogyakarta: Universitas Negeri Yogyakarta

Departemen Pendidikan dan Kebudayaan, Kamus Besar Bahasa Indonesia, Jakarta: PT. Balai Pustaka, 199I hal.I49

Hendrawan. Saryono, Djoko. Supriyono. 2016. Konsep dan Pedoman Penguatan Pendidikan Karakter Tingkat Sekolah Dasar dan Sekolah Menengah Pertama. Kementerian Pendidikan dan Kebudayaan Republik Indonesia.

Ibrohim. 2017. Penguatan Pendidikan Karakter Melalui Pembelajaran MIPA. Malang: Universitas Negeri Malang.

Karyanti, Muhammad Andi Setiawan. 2018. Model Konseling Kelompok Teknik Expresif Writing Berlandaskan Falsafah Dandang Tingang Untuk Meningkatkan Perilaku Respect. JURKAM: Jurnal Konseling Andi Matappa, 2(2): I29-I 36.

Koesoema, Doni. Suhardi, Didik. Muhammad, Hamid. 2017. Modul Pelatihan Penguatan Pendidikan Karakter Bagi Guru. Vol. 2. Pusat Analisis dan Sinkronisasi Kebijakan Sekretariat Jenderal Kementerian Pendidikan dan Kebudayaan.

Peraturan Presieden Republik Indonesia Nomor 87 Tahun 2017 tentang Penguatan Pendidikan Karakter

Putra, Chandra Anugrah. 2016. Pengaruh Strategi Pembelajaran Berbasis Proyek Perancangan dan Kecerdasan LogikMatematik Terhadap Kompetensi Merancang Web. Jurnal Teknologi Pendidikan, I8(2):90-I0I.
Setiawan, M Andi. 20I5. Model konseling kelompok dengan teknik problem solving untuk meningkatkan self-efficacy akademik siswa. Jurnal Bimbingan Konseling 4(I).

Utami, A. Titi. 20l4. Pelaksanaan Nilai Religius Dalam Pendidikan Karakter di SD Negeri I Kutowinangun Kebumen. Yogyakarta: Universitas Negeri Yogyakarta 